\title{
Preliminary results on the effects of grape (Vitis vinifera) seed condensed tannins on in vitro intestinal digestibility of the lupin (Lupinus angustifolius) seed protein fraction in small ruminants
}

\author{
A. M. Bruno-Soares ${ }^{1}$, A. L. Soares-Pereira ${ }^{1}$, T. J. S. Matos ${ }^{1}$ and J. M. Ricardo-da-Silva ${ }^{2}$ \\ 1 Instituto Superior de Agronomia, Universidade Técnica de Lisboa, Centro de Engenharia dos Biossistemas (CEER), Tapada da Ajuda, Lisboa, \\ Portugal, and \\ 2 Instituto Superior de Agronomia, Universidade Técnica de Lisboa, Laboratório Ferreira Lapa (Sector de Enologia), Tapada da Ajuda, Lisboa, \\ Portugal
}

Keywords:

lupin seed, crude protein degradability, intestinal digestibility, sheep

\section{Correspondence}

A. M. Bruno-Soares, Instituto Superior de Agronomia (CEER), Technical University of Lisbon, Tapada da Ajuda, 1349-017 Lisboa, Portugal.

Tel: +351 213653407; Fax: +351 213653195;

E-mail: abs@isa.utl.pt

Received: 9 March 2010;

accepted: 6 July 2010

\begin{abstract}
Summary
Condensed tannins (CT) from grape seeds (Vitis vinifera L.) were added to complex the protein fraction of Lupinus angustifolius seeds. Three CT/ protein ratios were used: $96 \mathrm{mg} / \mathrm{g}\left(T_{1}\right), 180 \mathrm{mg} / \mathrm{g}\left(T_{2}\right)$ and $0 \mathrm{mg} / \mathrm{g}\left(T_{0}\right)$. The CP losses in the rumen were assessed by the nylon-bag technique and $\mathrm{CP}$ intestinal digestibility (CPID) was estimated using an in vitro assay applying a three-step procedure: samples were subject to rumen degradation (in situ, $16 \mathrm{~h}$ ) and the remaining residues were subject to the digestive enzymes of the abomasum and pancreas in vitro. A positive effect $(p<0.05)$ of the level of CT on the immediately soluble faction $a$ and the insoluble degradable fraction $b$ was observed between $T_{0}$ and $T_{2}$. In the presence of $\mathrm{CT}$ the rumen degradation rate was reduced $(\mathrm{p}<0.05)$ from $0.0763 / \mathrm{h}\left(T_{0}\right)$ to $0.0443 / \mathrm{h}\left(T_{2}\right)$. The application of CT showed a reduction (around $10 \%$ for $T_{1}$ ) of effective rumen CP degradability. The CPID did not seem to be affected $(p>0.05)$ by the presence of CT. These findings suggest that the use of grape seed CT might have the potential to improve the efficiency of utilisation of the protein fraction from lupin seeds.
\end{abstract}

\section{Introduction}

Lupin grains are important protein sources in ruminant feeding in extensive Mediterranean production systems, especially in south of Portugal. However, these grains are known for their high rumen degradability, which in some cases reaches $90 \%$ (Van Straalen and Tamminga, 1990; Yu, 1995) leading to inefficient use of nitrogen in microbial protein synthesis. The presence of condensed tannins (CT) in ruminant diets reduces protein degradation by forming reversible complexes with proteins (McNabb et al., 1996; Salawu et al., 1999). These complexes enable protein to bypass degradation in the rumen and promote post-ruminal enzymatic hydrolysis and absorption (Salawu et al., 1999; Min et al., 2005). The increase in rumen undegraded protein (RUP) does not seem to imply a change in intestinal digestibility. Andrabi et al. (2005) reported similar levels for intestinal digestibility of protein with and without CT.

The aim of this work was to evaluate the efficiency of a so far rarely investigated form of dietary CT, grape seeds, to improve the utilization of the protein fraction of lupins with respect to the intestinal digestibility of rumen escape protein. For that, two levels of CT were investigated. 


\section{Materials and methods}

Feeds and feed analyses

Seeds of Lupinus angustifolius var. Tanjil obtained from Department of Agriculture and Food, Western Australia (DAFWA) were used. These lupin seeds were ground $(1 \mathrm{~mm})$ and samples were assessed for dry matter (DM) after drying at $100-105^{\circ} \mathrm{C}(24 \mathrm{~h})$, for ash by combustion at $550{ }^{\circ} \mathrm{C}(24 \mathrm{~h})$, for crude protein $(\mathrm{CP})$ by the Kjeldahl method $(N \times 6.25)$ and for ether extract (EE) by Soxhlet extraction. Neutral detergent fibre (NDF; amylase - Termamyl $120 \mathrm{~L}$ Type L Novozymes), acid detergent fibre and acid detergent lignin (ADL; sulphuric acid - Panreac, PAISO $96 \%$ ) were determined according to Van Soest et al. (1991) without correction for ash content. The isoelectric $\mathrm{pH}(\mathrm{pI})$ of the lupin seed protein fraction was determined according to Inklaar and Fortuin (1969). In this method a lupin sample containing $25 \mathrm{mg}$ of $N$ was used for each $\mathrm{pH}$ unit in the study (from 1 to $10 \mathrm{pH}$ units) and the $\mathrm{pH}$ was adjusted with $\mathrm{HCl}$ (Panreac, PA-ISO 99.5\%) and/or $\mathrm{NaOH}$ (Panreac, PA-ACS-ISO). After adjusting the $\mathrm{pH}$, each sample was centrifuged and the soluble protein in the supernatant was determined using Kjeldahl's method.

CT (La Gardonnenque SCA, Gruviers-Lascours, France) extracted from grape seeds (Vitis vinifera L.) were used to complex the lupin seed protein fraction. In order to characterise the CT, three fractions were obtained following Sun et al. (1998a) distinguished by their degree of polymerisation $(\mathrm{dP})$ : a monomeric fraction (monomer flavan-3-ols or catechins), a oligomeric fraction ( $\mathrm{dP}$ ranging from 2 to 12-15) and a polymeric fraction (dP $>12-15)$, using C18 Sep-Pak column (Waters Corporation, Milford, MA, USA). For each fraction the flavanol quantification was performed by the modified vanillin assay described by Sun et al. (1998b).

\section{Sample preparation}

The lupin seeds were milled to pass a $2 \mathrm{~mm}$ mesh and divided in three equal portions for the application of three CT levels $\left(T_{0}, T_{1}\right.$ and $\left.T_{2}\right)$ equivalent to 0 (control), 96 and $180 \mathrm{mg} / \mathrm{g} \mathrm{CP}$. The ground lupin seeds $(5 \mathrm{~g})$ were placed in ceramic capsules. The CT $\left(T_{1}\right.$ and $\left.T_{2}\right)$ were dissolved in $15 \mathrm{ml}$ of aqueous acetone (Panreac, PA ISO $100 \%)$ solution $(70: 30 \mathrm{v} / \mathrm{v}$ acetone:water) and added to each capsule. In the case of $T_{0}$, this consisted of the solution only. The ceramic capsules containing the milled lupin seeds and the CT-acetone solution were placed into a forced draught oven for $24 \mathrm{~h}$ at $40{ }^{\circ} \mathrm{C}$ to form a tablet.

\section{Rumen CP degradability and CP intestinal digestibility}

Three castrated male rumen-cannulated rams ( 3 years of age, $58 \mathrm{~kg}$ average live weight, Merino breed) were housed in metabolic cages and received $700 \mathrm{~g}$ of chopped hay (oats, Avena sativa $\times$ vetch, Vicia sativa) (90 g CP/kg DM and $591 \mathrm{~g} \mathrm{NDF} / \mathrm{kg} \mathrm{DM})$ and $300 \mathrm{~g}$ of a concentrate meal $(330 \mathrm{~g} \mathrm{CP} / \mathrm{kg}$ DM and $303 \mathrm{~g} \mathrm{NDF} / \mathrm{kg} \mathrm{DM}$ ), in two identical daily meals, at $08: 30$ and $16: 30 \mathrm{~h}$.

The CP losses in the rumen were assessed using the nylon bag ( $42 \mu \mathrm{m}$ pore size) technique (Ørskov et al., 1980). One nylon bag (size $14 \times 7 \mathrm{~cm}$ ) containing one previously formed tablet (ca. $5 \mathrm{~g}$ ) was used per treatment, animal and incubation time. This procedure was repeated in three consecutive runs. The bags were introduced into the rumen before the $08: 30 \mathrm{~h}$ meal and removed 3, 6, 9, 16, 24, 48 and $72 \mathrm{~h}$ later. Once removed, bags were washed in a washing machine $\left(30 \mathrm{~min}\right.$ at $37^{\circ} \mathrm{C}$, without spinning), and dried at $50{ }^{\circ} \mathrm{C}$ for $72 \mathrm{~h}$. Subsequently the residual DM and $\mathrm{CP}$ amounts were determined. Washing losses at $0 \mathrm{~h} \quad(t=0)$ were determined using two bags per treatment and run without previous rumen incubation, and losses were assessed as mentioned above for other residues (Bruno-Soares et al., 2000).

Crude protein degradability (CPD) kinetics were described by the model $p=a+b\left(1-\mathrm{e}^{-c t}\right.$ ) (Ørskov and McDonald, 1979) where $a$ is the immediately soluble fraction, $b$ the insoluble but slowly degradable fraction, $c$ the rate constant for the degradation of fraction $b, p$ the CP degradation after time $t$ and $(a+b)$ the CP potential degradability. The effective CPD (ECPD) in the rumen was calculated according to the equation, $\mathrm{ECPD}=a+b[c /(c+k)]$ where $a, b$, and $c$ are regression parameters from the non-linear model as described above and $k=0.05 \% \mathrm{~h}^{-1}$.

The crude protein intestinal digestibility (CPID) assessments were carried out using the procedure described by Calsamiglia and Stern (1995) and applying a rumen pre-incubation time of $16 \mathrm{~h}$. In this three-step procedure, the samples were subjected to rumen degradation (in situ) and the remaining residues were subjected to the digestive enzymes of the abomasum and pancreas in vitro. After rumen pre-incubation, bags and residues were washed and dried at $40{ }^{\circ} \mathrm{C}$ for $72 \mathrm{~h}$. Residues pooled by run containing $15 \mathrm{mg}$ of nitrogen were incubated 
in a pepsin (1 g/l; Sigma P-7012, Sigma, Aldrich, Germany) $\mathrm{HCl}$ [ $\mathrm{HCl} 0.01 \mathrm{~N}(\mathrm{pH} \approx 2)$ ] solution. After incubation, $\mathrm{pH}$ was neutralised and pancreatic solution was added consisting of a buffer solution of potassium phosphate (Sigma, PA ISO 99\%, $0.5 \mathrm{M}$, $\mathrm{pH} 7.8$ ) containing $50 \mathrm{ppm}$ of thymol (Sigma, PA ISO $96 \%$ ) and $3 \mathrm{~g} / \mathrm{l}$ of pancreatin (Sigma 7545). After $24 \mathrm{~h}$ incubation period, a TCA acid solution (100\%; Panreac, Barcelona, Spain, PA ACS 99.5\%) was added to terminate the enzymatic activity and to precipitate the undigested proteins. The $N$ content in the supernatant was measured by the Kjeldahl method corresponding to the soluble $N$.

\section{Statistical analysis}

The degradation parameters $(a, b$ and $c)$ were estimated by adjusting the $N$ losses in the rumen to the model $p=a+b\left(1-\mathrm{e}^{-c t}\right)$ using eight observation points $(0,3,6,9,16,24,48$ and 72 h). The adjustments were carried out using the Marquardt method of the PROC NLIN procedure of the s-PLUS 2000 software. Data on $a, b, c,(a+b)$, ECPD and CPID were subjected to ANOvA $I$ test, using the Duncan test for comparison of means (Duncan 1995) with SAS version 9.1 (SAS Inc., Cary, NC, USA) software.

\section{Results and discussion}

The lupin seed contained ( $\mathrm{g} / \mathrm{kg}$ original substance) $336 \mathrm{~g} \mathrm{CP}, 57 \mathrm{~g} \mathrm{EE}, 246 \mathrm{~g} \mathrm{NDF}, 188 \mathrm{~g} \mathrm{ADF}$ and $19 \mathrm{~g}$ ADL. The total content of CT of the grape seed extract was $634.8 \mathrm{~g} / \mathrm{kg}$, where 156, 195 and 424 $\mathrm{g} / \mathrm{kg}$ were represented by the monomer (catechins), oligomeric and polymer fractions, respectively. It is in agreement with results previously obtained for grape seed CT that polymers represented the largest fraction (Sun et al., 2001; Spranger et al., 2008; Cosme et al., 2009).

Values of the degradation parameters and the ECPD of the control treatment (Table 1) were slightly lower than those obtained by Dixon and Hosking (1992) as well as Bruno-Soares and Campos-Andrade (2002). As the same methodology had been used, the different results may be attributed to the different varieties of lupin studied, to the source of CT and to the use of acetone as a solvent.

The in situ degradation parameters of lupin seed protein varied with CT addition ( $\mathrm{p}<0.05$; Table 1$)$. The immediately soluble fraction $a$ decreased significantly, while the fraction $b$ increased $(\mathrm{p}<0.05)$. The degradation rate $c$ was significantly different between treatments $(p<0.05)$ decreasing with the increasing
Table 1 Actual CP losses, rumen CP degradation parameters $(a, b, c)^{*}$, effective rumen CPD (ECPD) and CPID of Lupinus angustifolius seeds exposed to different tannin concentrations

\begin{tabular}{|c|c|c|c|c|}
\hline \multirow[b]{2}{*}{ Incubation time (h) } & \multicolumn{4}{|c|}{ Treatment $\uparrow$} \\
\hline & $T_{0}$ & $T_{1}$ & $T_{2}$ & SEM \\
\hline \multicolumn{5}{|l|}{ CP losses (g/g DM) } \\
\hline 0 & 0.240 & 0.223 & 0.240 & \\
\hline 3 & 0.491 & 0.399 & 0.337 & \\
\hline 6 & 0.539 & 0.447 & 0.384 & \\
\hline 9 & 0.607 & 0.524 & 0.460 & \\
\hline 16 & 0.734 & 0.631 & 0.580 & \\
\hline 24 & 0.887 & 0.855 & 0.850 & \\
\hline 48 & 0.983 & 0.981 & 0.981 & \\
\hline 72 & 0.991 & 0.989 & 0.990 & \\
\hline \multicolumn{5}{|c|}{ Degradation parameters } \\
\hline$a(g / g D M)$ & $0.287^{\mathrm{a}}$ & $0.236^{\mathrm{b}}$ & $0.214^{b}$ & 0.005 \\
\hline$b(g / g D M)$ & $0.710^{\mathrm{a}}$ & $0.802^{\mathrm{b}}$ & $0.852^{c}$ & 0.004 \\
\hline$c\left(h^{-1}\right)$ & $0.0763^{\mathrm{a}}$ & $0.0590^{\mathrm{ab}}$ & $0.0443^{b}$ & 0.003 \\
\hline RSD & 1.89 & 1.93 & 2.17 & \\
\hline $\mathrm{ECPD}_{\left(K^{\S}=0.05 \% \mathrm{~h}^{-1}\right)}$ & $0.713^{\mathrm{a}}$ & $0.644^{b}$ & $0.609^{b}$ & 0.004 \\
\hline $\mathrm{CPID}_{(16 h)}$ & 0.724 & 0.701 & 0.700 & 0.012 \\
\hline
\end{tabular}

SEM, standard error of the mean; Values in the same row with unequal superscripts differ significantly $(p>0.05)$.

*Constants of the Ørskov and McDonald (1979) model (a: immediately soluble fraction; $b$ : insoluble but slowly degradable fraction; $c$ : degradation rate of $b$ fraction).

$\dagger T=$ condensed tannin:protein ratio; $T_{0}=0 \mathrm{mg} / \mathrm{g} ; T_{1}=96 \mathrm{mg} / \mathrm{g}$; and

$T_{2}=180 \mathrm{mg} / \mathrm{g}$.

"RSD: residual standard deviation of the fitted model.

${ }^{\S} k$ is the outflow rate.

tannin levels. CP losses in the rumen (Fig. 1) shown a positive response $(\mathrm{p}<0.05)$ between the CT level added and its effect. This can be explained by the limited access of rumen micro-organisms to this substrate which promote a decrease in the CP degradation rate. The results obtained are in agreement with studies of Salawu et al. (1999) where the pattern of CP disappearance was similar and where silage treated with CT resulted in a significantly lower percentage of protein disappearance in the rumen than in control.

The ECPD results indicated a decrease in rumen degradability $(p<0.05)$ when grape seed CT were added to lupin seeds. The ECPD showed that $T_{2}$ had a numerically greater effect on ECPD decrease than $T_{1}\left(T_{1}=9.7 \%\right.$ and $T_{2}=14.6 \%$ ECPD reduction $)$. However, the ECPD reduction was not proportional to the twofold increase in CT level $T_{2}$ compared to $T_{1}$. Bruno-Soares and Campos-Andrade (2002) observed the same tendency with lupin seeds and different quebracho CT levels. Using treatment $T_{2}$ the increase in $1 \mathrm{mg}$ of $\mathrm{CT}$ resulted in a reduction of $0.08 \%$ in ECPD whereas using $T_{1}$ resulted in a 


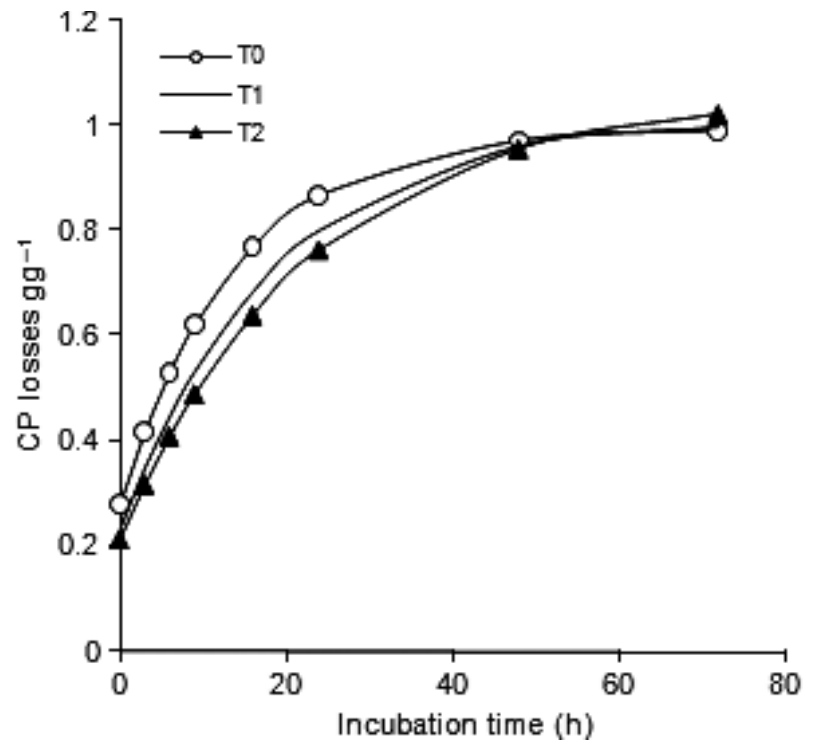

Fig. 1 Crude protein (CP) degradation kinetics in rumen of Lupinus angustifolius seeds with 3 levels of condensed tannins-CT (TO, $0 \mathrm{mg}$ CT/g CP; T1, $96 \mathrm{mg} \mathrm{CT/g} \mathrm{CP} \mathrm{and} \mathrm{T2,} 180 \mathrm{mg} \mathrm{CT/g} \mathrm{CP).}$

reduction of $0.10 \%$ in ECPD, making the latter more efficient.

The CT reactivity depends on its quantity and biological activity and also on the structure of the proteins with which they are binding (Andrabi et al., 2005). The solubility of the CT/protein complexes appears to be a function of the $\mathrm{CT} /$ protein ratio and other environmental factors, such as $\mathrm{pH}$, temperature, and solution polarity (Mueller-Harvey and McAllan, 1992). In the present study, three factors where controlled through the binding operation occurring at a $\mathrm{pH}$ close to the lupin protein $\mathrm{pI}$ and at a temperature that did not influence the stability of either compound. Temperatures lower than $60^{\circ} \mathrm{C}$ were used once, according to Haslam (1966), temperatures above $60{ }^{\circ} \mathrm{C}$ can cause heat damage and polymerisation may occur. The lupin protein used presented a pI of 5 and the $\mathrm{pH}$ of the CT solutions was of six. These $\mathrm{pH}$ values are in accordance with Hagerman and Butler (1978) studies which indicated that tannin-protein binding occurred at an optimal level, namely, within one $\mathrm{pH}$ unit of the protein $\mathrm{pI}$. According with these results, the $\mathrm{pH}$ of the mixture (milled seeds plus CT-acetone solution) should have a minimal influence on the CT/protein interaction.

With respect to in vitro RUP digestibility, there were no differences between $T_{0}, T_{1}$ and $T_{2}$ $(p>0.05)$. These results are consistent with what had been reviewed by Min et al. (2003) where the digestion conditions released the bond between tannins and protein and also with the study of Andrabi et al. (2005) where the CT had a minimal effect on the availability of dietary protein for post-rumen digestion. Accordingly, the two levels of tannins applied caused an increase in RUP without decreasing the abomasal and small intestinal RUP digestibility as estimated in vitro.

The use of grape seed CT therefore could have potential to improve lupin seed protein use efficiency. However, further research should be performed to confirm and to consolidate these findings, namely to assess the influence of the CT on the composition and on the profiles of essential amino acids of RUP. Moreover, in vivo experiments should be carried out to confirm the benefits of the grape seed CT addition on the CP fraction.

\section{Acknowledgements}

The authors are grateful to Dr Bevan Buirchell (DAFWA) for the lupin seeds supply. Financial assistance was provided by the POCTI /CVT project.

\section{References}

Andrabi, S. M.; Ritchie, M. M.; Stimson, C.; Horadagoda, A.; Hyde, M.; McNeil, D. M., 2005: In vivo assessment of the ability of condensed tannins to interfere with the digestibility of plant protein in sheep. Animal Feed Science and Technology 122, 13-27.

Bruno-Soares, A. M.; Campos-Andrade, M. P., 2002: Effect of Lupinus albus, L. luteus and L. angustifolius seed tannins on effective protein degradability in rumen. In: E. van Santen (ed.) Wild and Cultivated Lupins from the Tropics to the Poles. Proceedings of the 10th International Lupin Conference, Laugarvatn, Iceland.

Bruno-Soares, A. M.; Abreu, J. M. F.; Guedes, C. V. M.; Dias-da-Silva, A. A., 2000: Chemical composition, DM and NDF degradation kinetics in rumen of seven legume straws. Animal Feed Science and Technology 83, 75-80.

Calsamiglia, S.; Stern, M. D., 1995: A three-step in vitro procedure for estimating intestinal digestion of protein in ruminants. Journal of Animal Science 73, 1459-1465.

Cosme, F.; Ricardo-da-Silva, J. M.; Laureano, O., 2009: Tannin profiles of Vitis vinifera L. cv. red grapes growing in Lisbon and from their monovarietal wines. Food Chemistry 112, 197-204.

Dixon, R. M.; Hosking, B. J., 1992: Nutritional value of grain legumes for ruminants. Nutritional Research Review 5, 19-43.

Duncan, D. B., 1955: Multiple range and multiple $F$ tests. Biometrics 11, 1-42. 
Hagerman, A. E.; Butler, L. G., 1978: Protein precipitation method for the quantitative determination of tannins. Journal of Agricultural Food Chemistry 26, 809-812.

Haslam, E., 1966: Chemistry of Vegetable Tannins. Academic Press, New York.

Inklaar, P. A.; Fortuin, J., 1969: Determining the emulsifying and emulsion stabilising capacity of protein meat additives. Journal of Food Technology 41, 103-107.

McNabb, W. C.; Waghorn, G. C.; Peters, J. S.; Barry, T. N., 1996: The effect of condensed tannins in Lotus pedunculatus upon the solubilisation and degradation of ribulose-1,5-biphosphate carboxylase (Rubisco) protein in the rumen and the sites of Rubisco digestion. British Journal of Nutrition 76, 535-549.

Min, B. R.; Barry, T. N.; Attwood, G. T.; McNabb, W. C., 2003: The effect of condensed tannins on the nutrition and health of ruminants fed fresh temperate forages: a review. Animal Feed Science and Technology 106, 3-19.

Min, B. R.; Attwood, G. T.; McNabb, W. C.; Molan, A. L.; Barry, T. N., 2005: The effect of condensed tannins from Lotus corniculatus on the proteolytic activities and growth of rumen bacteria. Animal Feed Science and Technology 121, 45-58.

Mueller-Harvey, I.; McAllan, A. B., 1992: Tannins: their biochemistry and nutritional properties. Advanced Plant Cell Biochemistry and Biotechnology 1, 151-217.

Ørskov, E. R.; McDonald, I., 1979: The estimation of protein degradability in the rumen from incubation measurements weighted according to rate of passage. Journal of American Science 92, 449-453.

Ørskov, E. R.; Hovell, F. D.; Mould, F., 1980: The use of nylon bag technique for evaluation of feedstuffs. Tropical Animal Production 5, 195-223.
Salawu, M. B.; Acamovic, T.; Stewart, C. S.; Hvelplund, T.; Weisbjerg, M. R., 1999: The use of tannins as silage additives: effect on silage composition and mobile bag disappearance of dry matter and protein. Animal Feed Science and Technology 82, 243-259.

Spranger, M. I.; Sun, B. S.; Mateus, A. M.; De Freitas, V.; Ricardo-da-Silva, J. M., 2008: Chemical characterisation and antioxidant activities of oligomeric and polymeric procyanidin fractions from grape seeds. Food Chemistry 108, 519-532.

Sun, B. S.; Leandro, M. C.; Ricardo-da-Silva, J. M.; Spranger, M. I., 1998a: Separation of grape and wine proanthocyanidins according to their degree of polymerisation. Journal of Agricultural and Food Chemistry 46, 1390-1396.

Sun, B. S.; Ricardo-da-Silva, J. M.; Spranger, M. I., 1998b: Critical factors of vanillin assay for catechins and proanthocyanidins. Journal of Agricultural and Food Chemistry 46, 4267-4274.

Sun, B. S.; Ricardo-da-Silva, J. M.; Spranger, M. I., 2001: Quantification of catechins and proanthocyanidins in several Portuguese grapevine varieties and red wines. Ciência e Técnica Vitivinícola 16, 23-24.

Van Soest, J. P.; Robertson, J. B.; Lewis, B. A., 1991: Methods for dietary fibre, neutral detergent fibre and non starch polysaccharides in relation to animal nutrition. Journal of Dairy Science 74, 3583-3594.

Van Straalen, W. M.; Tamminga, S., 1990: Protein degradation in ruminant diets. In: J. Wiseman, D.J.A. Cole (eds), Feed Evaluation. Butterworth, London, pp. 55-72.

Yu, P., 1995: Influence of pressure toasting on rumen degradation characteristics and in vitro digestibility of horsebean. MSc thesis, Landbouw Universiteit Wageningen, The Netherlands. 